\author{
Lenka ŠTOFOVÁ ${ }^{1}$ \\ Petra SZARYSZOVÁ ${ }^{2}$ \\ Lucia BEDNÁROVÁ \\ Artur KOTTNER ${ }^{4}$
}

\title{
ENVIRONMENTAL CRITERIA OF PUBLIC PROCUREMENT AS AN INSTRUMENT OF DEVELOPMENT SUSTAINABILITY OF SLOVAKIA
}

\begin{abstract}
Green or sustainable economic growth for environmental policy in the light of the current environmental crisis and resource depletion is discussed in various national and international political and expert levels. Indicators of green growth and statistical results can measure sustainable development, while they allow to evaluate the green growth and support its integration into policy.

The paper analyses the OECD's framework strategy with selection of important environmental indicators and characteristics, which are intended for the assessment of the green growth strategies (green marketing). The significance of criteria, which takes into account the price in terms of public procurement is relatively high, but the values of economic activities (sustainable production, sustainable consumption and trade) are relatively low. Results suggest that production and consumption must be environmentally and economically sustainable. Nowadays green growth strategy also in Slovakia emphasizes economic value, the country goes the right way and economic - environmental activities will grow in the future. This study offers a concept for measuring the general environmental effects of activities and evaluation of green public commissions based on phrased criteria and methodical plan of implementation of the green public commission. The methodology provides the information needed for national economic reform plans based on the present status report.
\end{abstract}

Keywords: sustainable development, green public procurement, sustainable production and consumption indicators, environmental criteria.

\section{INTRODUCTION}

Currently, many organizations headed off to sustainable development considering the "green" concept. Green Public Procurement (GPP) increasingly plays an important role in stimulating demand for environmentally friendly products and services, which makes necessary to analyze which characteristics significantly represent the integration of environmental criteria in setting the public procurement. Statistical analysis confirmed that by

\footnotetext{
${ }^{1}$ Ing. Lenka Štofová, University of Economics in Bratislava, Faculty of Business Economics with seat in Košice, Slovak Republic, corresponding author: e-mail:lenka.stofova@euke.sk

2 Ing. Petra Szaryszová PhD., University of Economics in Bratislava, Faculty of Business Economics with seat in Košice, Slovak Republic

3 Doc. Lucia Bednárová PhD. University of Economics in Bratislava, Faculty of Business Economics with seat in Košice, Slovak Republic

${ }^{4}$ Ing. Artur Kottner PhD., University of Central Europe, Skalica, Slovak Republic
} 
intesification of information and raising awareness on GPP can greatly promote the development of green public procurement.

It shows that efficiency of GPP can not be achieved by simple approval of certified environmental management system (EMS), but rather through the level of maturity of the development of certified EMS and gratuitous instruments of environmental policy that provide a increasing "added value" to the GPP practices.

The corresponding proportioning of individual environmental requirements in the form of environmental indicators related to the competence of the public authorities may represent progress in GPP, realized from european, national and local supportive initiatives.

\section{GREEN PUBLIC PROCUREMENT AS A TOOL OF SUSTAINABLE DEVELOPMENT}

Policies and practices of sustainable development are related to economics, environment and society. An essential example is the necessary change of philosophy in the way how we understand the limitations on time, costs and quality. In the context of public procurement and in order to accomplish the organization's requirements for goods and services in sustainable achieving the goals is useful to specify the significance and mutual dependance of individual criteria and benefits regarding the external factors ${ }^{5}$.

To achieve these goals is necessary to the decision-making framework incorporate external costs with conventional criteria for public procurement in price and quality. These considerations are usually transferred to: environmental, economic and social criteria (also known as "Triple baseline").

According to Bouwer the green procurement is defined as "access by which the public authorities integrate environmental criteria into all phases of the process of their procurement and by that they promote the dissemination of environmental technologies and the development of environmentally friendly products by searching and choosing outcomes and solutions that have the least impact on the environment during their life cycle"6.

It is a process of expenses and investments related to public order which is valid to private sector as well. GPP is connected to broader agenda of sustainable development organizations which practise sustainable public procurement by meeting their requirements that are not only for the private cost-benefit analysis, but also to maximalize the net of benefits and the purchase of preferred environmentally friendly products and services in accordance with one or more characteristics of the green public procurement ${ }^{7,8}$.

\footnotetext{
${ }^{5}$ Bednárová, L., Liberko, I. 2009. Benchmarking v riadení podnikov. Roland Weiss. In: Acta Montanistica Slovaca. - 14, č. 1 (2009), pp. 86-91. ISSN 1335-1788.

${ }^{6}$ Bouwer, M., de Jong, K., Jonk, M., Berman, T., Bersani, R., Lusser, H., Nissinen, A., Parikka, K., Szuppinger, P. 2005. Green Public Procurement in Europe 2005 -Status Overview. Virage Milieu \& Management, Haarlem, The Netherlands. Available: http://ec.europa.eu/environment/gpp/pdf/Stateofplaysurvey2005_en.pdf.

${ }^{7}$ Bednárová,L., Liberko,I., Rovnák, M. 2013. Environmental benchmarking in small and medium sized enterprises and there impact on environment,. In Ecology, economics, education and legislation : conference proceedings, volume II : 13th international multidisciplinary scientific geoconference SGEM 2013, Sofia : STEF92 Technology, 2013, S. 141-146, ISBN 978-619-7105-05-6.

${ }^{8}$ Kottner, A., Štofová, L., Lešková, L., Tarča, A. 2015. Metodika integrácie environmentálnych aspektov do procesu verejného obstarávania. In Technické vedy a výrobný manažment 2015: zborník abstraktov z medzinárodnej vedeckej konferencie : Vysoké Tatry, Tatranská Štrba, 16.4.-17.4.2015. -
} 
In a comparison to a standard equivalent, green public procurement represents the purchase of products or services which minimize the negative impact on the environment during their life cycle. It includes the integration of environmental doubts to other decision making based on price, performance and quality. Products and services that consume less natural resources should have a priority over competing products with a bigger impact on the environment ${ }^{9}$ (Fig. 1).

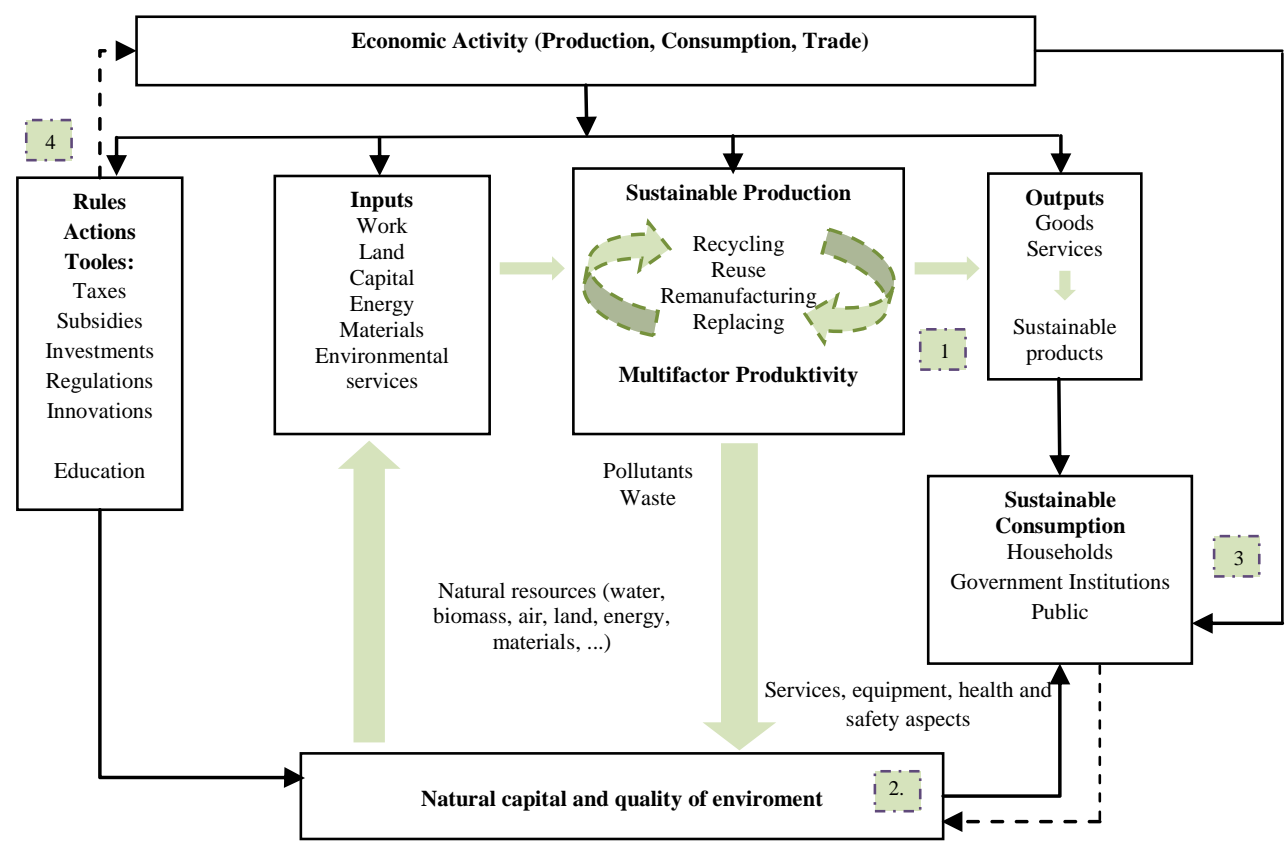

1: Indicators monitoring the environmental efficiency of production / consumption and the changes in accesses to the production / consumption

2: Indicators monitoring the environmental natural base

3: Indicators monitoring the environmental quality of life (objective, subjective)

Figure 1. Indicators of sustainable green growth

Source: own processing.

Košice : Katedra manažmentu, Podnikovohospodárska fakulta so sídlom v Košiciach, Ekonomická univerzita v Bratislave, 2015. - ISBN 978-80-971555-4-4. - S. 101.

${ }^{9}$ OECD. 2013. OECD Compendium of Agri-environmental Indicators. OECD Publishing, Paris, http://dx.doi.org/ 10.1787/9789264186217-en. 


\section{RECOMMENDED FRAMEWORK CONDITIONS ACCORDING TO THE EU GREEN PUBLIC PROCUREMENT}

There are several countries using very similar evidence for environmental criteria. They most often refer to Environmental Facility Data LCA (Life Cycle Analysis), along with the environmental labeling and other evidence. The EU GPP program states that it is not necessary to establish a framework for EU GPP scheme, but rather a series of recommendations for the implementation of green public procurement. Some of the environmental aspects are already part of the process of GPP applicable to scientific evidence and for stakeholders. Other recommendations for extending important areas include for example a consideration of social aspects of all product groups (where possible) and a preference of GPP criteria developed within product groups that undergo a policy review and update of the EC EU. The final evaluation of national programs allows to make recommendations in detail to update the EU framework for determining criteria. The recommended framework consists of two parts: the scheme and the criteria.

The green public procurement scheme includes the following requirements ${ }^{10}$ :

1. The main objective of the scheme should be clear and directly related to EU policy.

2. The determination of the EU GPP Advisory Group with ultimate responsibility for the development of EU GPP criteria.

3. Prioritization and choice of products should be evidence-based and transparent.

4. Communication with external stakeholders.

5. Information concerning the overall schedule development must be available at the beginning through a specific external consultation process.

6. Carrying out continuous training programs and provision of supporting information as key element of the GPP program.The EU GPP criteria are designed to facilitate the integration of green requirements in public tender documents. While the adopted EU GPP criteria seek to strike a balance between environmental impact, costs, availability on the market and control, contracting entities may decide according to their needs and the level of ambition whether they should take account of all or only some of the requirements in their tender documents.

The criteria must be derived from the life-cycle based thinking. The process of sizing criteria must meet the following requirements ${ }^{11}$ :

1. Evidence used to formulate criteria must be transparent.

2. The scope of requirements that include relevant environmental criteria should be sustainable and, where possible and appropriate, may also include appropriate social criteria.

3. The criteria must be easy to use, both for professionals, contracting authority and for contracting suppliers.

4. The process of developing the criteria should be clear with a clear division of responsibilities for stakeholders.

5. A clear outline of the stages of the development of criteria for the periodic control of every stage of the process. The whole process should not take more than one year.

\footnotetext{
${ }^{10}$ OECD. 2013. Inventory of Estimated Budgetary Support and Tax Expenditures for Fossil Fuels 2013. OECD Publishing, Paris, http://dx.doi.org/10.1787/9789264187610-en.

11 Majerník, M., Szaryszová, P., Bosák, M., Štofová, L. \& Kabdi, K.. 2015. Integrated management of environmental - safety and technical risks of plant producing automobiles and automobile components. In Communications: scientific letters of the University of Žilina. - Žilina: University of Žilina, 2015. - ISSN 1335-4205. - Vol. 17, no. 1 (2015), pp. 28-33.
} 
6. Review of the criteria should be carried out regularly with a limited time frame. The revision should take place every year and at least every three years.

To identify environmental criteria according to requirements at the EU level, an expert way as well as a stratification method, based on discretion, experience and knowledge was used ${ }^{12}$.

The number of points for a given criteria indicator is essential to the extent to which these points can give direction to interested parties in the implementation of effective green public procurement of products. The result is the establishment of the importance of individual indicators criteria for a particular procurement of paper. The number of points for a particular Green contract paper is shown in Table 1.

Table 1. Criteria and assessment of green public procurement of office paper from the product group "copying and graphic paper

\begin{tabular}{|c|c|c|c|}
\hline $\begin{array}{c}\text { Criteria for the } \\
\text { Evaluation of Offer } \\
\left(\mathbf{K}_{\mathrm{R}}\right)\end{array}$ & Environmental Characteristics of Criteria & Points & $\begin{array}{c}\text { Tools } \\
\text { related to } \\
\text { EP }\end{array}$ \\
\hline \multirow{9}{*}{$\begin{array}{l}\text { 1. EMS based on } \\
\text { 14001 or EMAS III } \\
\text { (EMS) }\end{array}$} & $\begin{array}{l}\text { The certificate of EMS establishment according to } \\
\text { ISO } 14001\end{array}$ & 30 & \multirow{10}{*}{$\begin{array}{c}\text { EEL } \\
\text { IPP } \\
\text { ET } \\
\text { LCA } \\
\text { EPE } \\
\text { EMA }\end{array}$} \\
\hline & EMS registration in MAS III scheme (Logo EMAS) & 30 & \\
\hline & The initial environmental review & 10 & \\
\hline & Register of environmental aspects, impacts and risks & 10 & \\
\hline & Environmental policy & 10 & \\
\hline & $\begin{array}{c}\text { Environmental statement and its verification by the } \\
\text { environmental verifier }\end{array}$ & 10 & \\
\hline & Environmental audit & 20 & \\
\hline & Internal environmental audits & 20 & \\
\hline & Environmental reports & 10 & \\
\hline & Total & 150 & \\
\hline \multirow{5}{*}{$\begin{array}{l}\text { 2. Environmental } \\
\text { labeling of products } \\
\text { (EEL) }\end{array}$} & Certificate European Eco-label (the Europen Flower) & 20 & \multirow{6}{*}{$\begin{array}{c}\text { IPP } \\
\text { ET } \\
\text { LCA } \\
\text { EMS } \\
\text { EPE }\end{array}$} \\
\hline & Certificate national ecolabel type I (EVP, etc.) & 20 & \\
\hline & The Energy Star Labeling & 10 & \\
\hline & Energy labeling EU & 10 & \\
\hline & FSC, PEFC Certificate & 10 & \\
\hline & Total & 70 & \\
\hline
\end{tabular}

\footnotetext{
${ }^{12}$ Zelené verejné obstarávanie. 2013. Metodická príručka pre verejných obstarávatelov a obstarávatelov. Slovenská agentúra životného prostredia, Centrum odpadového hospodárstva a environmentálneho manažérstva.
} 


\begin{tabular}{|c|c|c|c|}
\hline \multirow{7}{*}{$\begin{array}{l}\text { 3. 3. Integrated } \\
\text { Product Policy } \\
\text { (IPP) }\end{array}$} & Regional / national brand of integrated production & 20 & \multirow{7}{*}{$\begin{array}{c}\text { EEL } \\
\text { LCA } \\
\text { EMS } \\
\text { ET } \\
\text { EPE } \\
\text { EMA }\end{array}$} \\
\hline & The patents relevant to Green growth & 20 & \\
\hline & The rate of waste recovery & 10 & \\
\hline & Evaluation of material demandingness & 10 & \\
\hline & Evaluation of life cycle costs & 10 & \\
\hline & Environmental innovations of products & 20 & \\
\hline & Total & 90 & \\
\hline \multirow{2}{*}{$\begin{array}{l}\text { 4. Environmental } \\
\text { technologies (ET) }\end{array}$} & Documents demonstrating BAT technology & 10 & \multirow{2}{*}{$\begin{array}{c}\text { IPP } \\
\text { LCA } \\
\text { EPE } \\
\text { EMS }\end{array}$} \\
\hline & Total & 10 & \\
\hline \multirow{6}{*}{$\begin{array}{c}\text { 5. Life Cycle } \\
\text { Assessment (LCA) }\end{array}$} & Implementation of LCA according to ISO 14044 & 20 & \multirow{6}{*}{$\begin{array}{c}\text { EEL } \\
\text { EPE } \\
\text { EMA } \\
\text { EMS }\end{array}$} \\
\hline & Register of environmental aspects, impacts and risks & 10 & \\
\hline & Inventory analysis & 5 & \\
\hline & Life Cycle Impact Assessment & 10 & \\
\hline & Interpretation of life cycle of product & 5 & \\
\hline & Total & 50 & \\
\hline \multirow{4}{*}{$\begin{array}{l}\text { 6. Environmental } \\
\text { Performance } \\
\text { Evaluation (EPE) }\end{array}$} & Implementation of EPE according to ISO 14031 & 20 & \multirow{4}{*}{$\begin{array}{c}\text { EEL } \\
\text { IPP } \\
\text { LCA } \\
\text { EMS }\end{array}$} \\
\hline & Register of environmental aspects, impacts and risks & 10 & \\
\hline & Evaluation of environmental performance indicators & 20 & \\
\hline & Total & 50 & \\
\hline \multirow{3}{*}{$\begin{array}{l}\text { 7. Environmental } \\
\text { management } \\
\text { accounting (EMA) }\end{array}$} & Implementation of EMA & 20 & \multirow{3}{*}{$\begin{array}{c}\text { IPP } \\
\text { LCA } \\
\text { EMS } \\
\text { EPE }\end{array}$} \\
\hline & $\begin{array}{l}\text { Material Flow Cost Accounting according to ISO } \\
14051\end{array}$ & 20 & \\
\hline & Total & 40 & \\
\hline \multirow{6}{*}{ 8. Other proofs } & Technical documentation of producer & 10 & \\
\hline & Test report by an accredited testing laboratory & 10 & \\
\hline & $\begin{array}{l}\text { A written declaration from producer about the } \\
\text { compliance with characteristics }\end{array}$ & 10 & \\
\hline & Labelling a cover of a product & 10 & \\
\hline & Total & 40 & \\
\hline & Total & 500 & \\
\hline
\end{tabular}

Source: own processing 
We have verified the correctness of individual characteristics and related environmental criteria using Pearson correlation coefficient and by coefficient of determination.

Stratified selection was carried out by dividing the basic file in areas after which in these areas we will make a random selection. Partitioning the basic file into more homogeneous areas and carrying out random selection in these areas will result in reducing the selection mean error and thereby in increase of the accuracy of estimates. In the created area we can apply characters about which we have sufficient data, can find them at each unit and are closely correlated with the explored characters. When selecting and proposing criteria it is necessary to clarify what improvements we can expect from the forthcoming product innovation and change. Nine criteria were selected with the appropriate grading points of significance (Table 2).

Table 2. Calculation variables $\mathrm{X}$ and $\mathrm{Y}$

\begin{tabular}{cc}
\hline $\mathbf{X}$ & $\mathbf{Y}$ \\
\hline $\mathbf{0 , 7 1 4}$ & 0,571 \\
$\mathbf{0 , 5 7 1}$ & 0,714 \\
$\mathbf{0 , 7 1 4}$ & 0,714 \\
$\mathbf{0 , 7 1 4}$ & 0,571 \\
$\mathbf{0 , 5 7 1}$ & 0,143 \\
$\mathbf{0 , 1 4 3}$ & 0,143 \\
$\mathbf{0 , 1 4 3}$ & 0,714 \\
\hline
\end{tabular}

Source: own processing

By using the Pearson correlation coefficient and from calculations for determining the rate of force and the relationship between different environmental criteria we came to conclusions subsribed in Table 2 and 3.

Table 3. Result details and Calculation

\begin{tabular}{|c|c|}
\hline X Values & $\begin{array}{c}\sum=3570 \\
\text { Mean }=255 \\
\sum\left(\mathrm{X}-\mathrm{M}_{\mathrm{x}}\right)^{2}=\mathrm{SS}_{\mathrm{x}}=1312018\end{array}$ \\
\hline Y Values & $\begin{array}{c}\sum=3570 \\
\text { Mean }=255 \\
\sum\left(\mathrm{Y}-\mathrm{M}_{\mathrm{y}}\right)^{2}=\mathrm{SS}_{\mathrm{y}}=1312018\end{array}$ \\
\hline$X$ and $Y$ Combined & $\begin{array}{c}N=14 \\
\sum\left(\mathrm{X}-\mathrm{M}_{\mathrm{x}}\right) \mathrm{x}\left(\mathrm{Y}-\mathrm{M}_{\mathrm{y}}\right)=1026732\end{array}$ \\
\hline R Calculation & $\begin{array}{c}\mathrm{r}=\sum\left(\left(\mathrm{X}-\mathrm{M}_{\mathrm{y}}\right) \mathrm{x}\left(\mathrm{Y}-\mathrm{M}_{\mathrm{x}}\right)\right) / \sqrt{ }\left(\left(\mathrm{SS}_{\mathrm{x}}\right) \mathrm{x}\left(\mathrm{SS}_{\mathrm{y}}\right)\right) \\
\mathrm{r}=1026732 / \sqrt{((1312018) \mathrm{x}(1312018))=0.7826}\end{array}$ \\
\hline Meta Numerics (cross-check) & $\mathrm{r}=0.7826$ \\
\hline Coefficient of determination & $\mathrm{R}^{2}=0.6125$ \\
\hline
\end{tabular}

Source: own proceeding 
The value of $\mathrm{R}$ is 0.7826 . This is a strong positive correlation, which means that high $\mathrm{X}$ variable scores go with high $\mathrm{Y}$ variable scores (and vice versa). The value of $\mathrm{R}^{2}$, the coefficient of determination, is 0.6125 .

The proposed methodology of realization of green public procurement with more exact concretization of individual criteria appears as an important and beneficial. The process of proportioning of criteria should continue to participate and strengthen the cooperation between the different instruments of environmental policy related to products.

\section{CONCLUSION}

Green public procurement represents political and legislative instrument with distinctive potential in decision making of procurers "producers" - to wend in development in sustainable direction. The purpose of the study was to propose a general methodology of realization of the green public procurement and purchasing based on precisely defined environmental criteria in relation to GPP in Slovakia from a strategic point of view of sustainability to promote highquality environmental friendly products.

The analysis as the part of the study for a particular commission shows that process of development of GPP criteria is transparent, well documented and strongly supports the implementation of green public procurement in Slovakia along with the other environmental policy instruments. The current process of green public procurement has some limitations as an ambiguous definition of environmental criteria of public procurement.The process of identification and proportioning of individual environmental GPP criteria depends primarily on the existing impacts on environment including the characteristics of environmental policy instruments, which are reflected in manuals on GPP and in Green Growth Strategies of OECD as well.

The methodology of identifying and proportioning of environmental criteria for GPP is created to be generally used in organizations in realization of specific green public procurement. By applying this methodology is possible to achieve business success along with achieving financial, social and environmental development goals by using environmentally friendly products supported by key concerned parties and motivation of producers, suppliers and procurers.

\section{ACKNOWLEDGEMENTS}

This contribution is a result of the Project for young teachers, researchers and $\mathrm{PhD}$ students, no. I-15-110-00, 2015: Methodology for implementation of Integrated Management for small and medium-sized enterprises in SR and EU levels.

\section{REFERENCES}

[1] Bednárová, L., Liberko, I. 2009. Benchmarking v riadení podnikov. Roland Weiss. In: Acta Montanistica Slovaca. - ISSN 1335-1788. - Roč. 14, č. 1 (2009), s. 86-91.

[2] Bednárová,L., Liberko,I., Rovňák, M. 2013. Environmental benchmarking in small and medium sized enterprises and there impact on environment,. In Ecology, economics, education and legislation : conference proceedings, volume II : 13th international multidisciplinary scientific geoconference SGEM 2013, Sofia : STEF92 Technology, 2013, S. 141-146, ISBN 978-619-7105-05-6.

[3] Bouwer, M., de Jong, K., Jonk, M., Berman, T., Bersani, R., Lusser, H., Nissinen, A., Parikka, K., Szuppinger, P. 2005. Green Public Procurement in Europe 2005 - 
Status Overview. Virage Milieu \& Management, Haarlem, The Netherlands. Available: http://ec.europa.eu/environment/gpp/pdf/Stateofplaysurvey2005_en.pdf.

[4] Kottner, A., Štofová, L., Lešková, L., Tarča, A. 2015. Metodika integrácie environmentálnych aspektov do procesu verejného obstarávania. In Technické vedy a výrobný manažment 2015: zborník abstraktov z medzinárodnej vedeckej konferencie : Vysoké Tatry, Tatranská Štrba, 16.4.-17.4.2015. - Košice : Katedra manažmentu, Podnikovohospodárska fakulta so sídlom v Košiciach, Ekonomická univer zita v Bratislave, 2015. - ISBN 978-80-971555-4-4. - S. 101.

[5] Majerník, M., Szaryszová, P., Bosák, M., Štofová, L. \& Kabdi, K.. 2015. Integrated management of environmental - safety and technical risks of plant producing automobiles and automobile components. In Communications: scientific letters of the University of Žilina. - Žilina: University of Žilina, 2015. - ISSN 1335-4205. Vol. 17, no. 1 (2015), pp. 28-33.

[6] OECD. 2013. Inventory of Estimated Budgetary Support and Tax Expenditures for Fossil Fuels 2013. OECD Publishing, Paris, http://dx.doi.org/ /10.1787/9789264187610-en.

[7] Zelené verejné obstarávanie. 2013. Metodická príručka pre verejných obstarávatel'ov a obstarávatelov. Slovenská agentúra životného prostredia, Centrum odpadového hospodárstva a environmentálneho manažérstva.

\section{KRYTERIA ŚRODOWISKOWE DOTYCZACE ZAMÓWIEŃ PUBLICZNYCH \\ JAKO INSTRUMENT ZRÓWNOWAŻONEGO ROZWOJU SŁOWACJI}

W artykule omówiono kwestie dotyczące zrównoważonego wzrostu ekonomicznego w ochronie środowiska w świetle obecnego kryzysu i uszczuplenia zasobów, które to zagadnienie poruszane jest podczas różnych krajowych i międzynarodowych dyskusji politycznych i eksperckich. Wskaźniki rozwoju ekologicznego i wyników statystycznych mogą mierzyć zrównoważony rozwój, pozwalają one na ocenę rozwoju ekologicznego oraz wspierają jego politykę integracji. W artykule autorzy analizują strategię ramową Organizacji Współpracy Gospodarczej i Rozwoju z uwzględnieniem ważnych wskaźników środowiskowych i cech, które są przeznaczone do oceny zielonych strategii wzrostu gospodarczego (zielony marketing). Znaczenie kryteriów, które biorą pod uwagę cenę w zakresie zamówień publicznych jest stosunkowo wysokie, ale wartości działalności gospodarczej (zrównoważona produkcja, zrównoważona konsumpcja i handel) są stosunkowo niskie. Wyniki sugerują, że produkcja i konsumpcja muszą być ekologicznie i ekonomicznie zrównoważone. Obecnie zielona strategia wzrostu także na Słowacji podkreśla wartość gospodarczą, kraj idzie właściwą drogą, a ekonomiczne i środowiskowe działania rozwiną się w przyszłości. Badanie to oferuje koncepcję pomiaru ogólnych skutków środowiskowej działalności i oceny zielonych komisji publicznych w oparciu o sformułowane kryteria, jak i metodyczny plan wdrażania zielonej komisji publicznej. Metodologia dostarcza informacji potrzebnych do krajowych planów reform gospodarczych na podstawie niniejszego raportu.

Słowa kluczowe: zrównoważony rozwój, zielone zamówienia publiczne, zrównoważone wskaźniki produkcji i konsumpcji, kryteria ekologiczne.

DOI:10.7862/rz.2016.hss.32

Przesłano do redakcji: czerwiec 2015

Przyjęto do druku: lipiec 2016 